\title{
MENINGKATKAN MOTIVASI BELAJAR SISWA DENGAN MENGGUNAKAN MODEL PEMBELAJARAN WORD SQUARE PADA PELAJARAN IPA DI KELAS V SD NEGERI 104204 SAMBIREJO TIMUR
}

\author{
Rouli Barimbing
}

Surel: halimunimed@gmail.com

\begin{abstract}
ABSTRAK
Penelitian ini bertujuan untuk meningkatkan motivasi belajar siswa pada pelajaran IPA. Jenis penelitian ini adalah Penelitian Tindakan Kelas (PTK) yang terdiri dari 2 Siklus. Subjek penelitian adalah siswa/i kelas III $^{\mathrm{A}}$ SD Negeri 104204 Sambirejo Timur sebanyak 36 orang siswa dengan jumlah laki-laki 20 orang dan perempuan 16 orang. Objek penelitian ini adalah penggunaan model pembelajaran Word Square untuk meningkatkan motivasi belajar siswa. Teknik pengumpulan data dalam penelitian ini menggunakan lembar observasi untuk guru, lembar observasi untuk siswa dan angket. Hasil observasi pelaksanaan Word Square oleh peneliti yang dilakukan oleh wali kelas III $^{\mathrm{A}}$ pada siklus I pertemuan I menghasilkan rata-rata $60 \%$ dengan kriteria sedang, pada siklus I pertemuan II meningkat menjadi $80 \%$ dengan kriteria baik, pada siklus II pertemuan I $80 \%$ dengan kriteria baik, dan pada siklus II pertemuan II meningkat menjadi 100\% dengan kriteria sangat baik.
\end{abstract}

Kata Kunci: Motivasi Belajar, Model Word Squere, IPA

\section{PENDAHULUAN}

Pembelajaran IPA merupakan mata pelajaran yang sarat akan materi sehingga siswa dituntut memiliki pemahaman yang holistik terhadap materi yang disampaikan guru. Dengan demikian siswa harus mengamati, mengkaji, dan mengaitkan materi pelajaran dari beberapa bidang kajian sekaligus untuk memahami suatu fenomena dari segala sisi.

Salah satu karakteristik pembelajaran IPA adalah mengutamakan peran aktif peserta didik baik secara fisik, mental, ataupun sosial sesuai dengan tingkat perkembangan dan lingkungan anak. Untuk menciptakan suasana belajar yang aktif dibutuhkan guru yang mempunyai kemampuan membuat perencanaan pengajaran, melakukan prosedur pengajaran dan melakukan interaksi antar pribadi yang terwujud dalam proses pembelajaran efektif.

Berdasarkan hasil observasi yang telah dilakukan di kelas V SD Negeri 104204 Sambirejo Timur, dapat diketahui bahwa rendahnya motivasi belajar siswa dalam pembelajaran IPA disebabkan minat belajar siswa terhadap pembelajaran

SD Negeri 104204 Sambirejo Timur 
IPA masih rendah. Kurangnya motivasi belajar siswa berdampak pada perolehan nilai belajar siswa. Dari keseluruhan siswa yang berjumlah 36 orang, sebanyak 8 orang saja, atau hanya sekitar $25 \%$ saja siswa yang dikatakan tuntas dari keseluruhan siswa. Sedangkan siswa yang dikatakan belum tuntas sebanyak 24 siswa atau sebanyak $75 \%$. Nilai KKM (Kriteria Ketuntasan Minimal) yang harus dicapai yaitu 70 . Model atau metode pembelajaran yang digunakan guru belum sesuai untuk meningkatkan motivasi belajar siswa. Guru cenderung menggunakan metode konvensional (ceramah, tanya jawab, pemberian tugas, dan latihan) saat proses pembelajaran. Hal itu menimbulkan kejenuhan pada siswa sehingga malas melaksanakan kegiatan pembelajaran di kelas. Pada saat guru menjelaskan, siswa tidak memperhatikan guru, siswa cenderung melakukan aktivitas sendiri dan bercerita dengan temannya. Ketika guru bertanya pun hanya tiga empat orang saja yang bisa menjawab, sedangkan hampir $88 \%$ siswa diam saja. Siswa kurang memiliki keberanian mengeluarkan pendapat.

Pengajaran IPA yang dilakukan cenderung teacher centered. Guru menjadi sumber informasi siswa. Komunikasi yang terjadi hanya searah, dimana sumber pembicaraan hanya berasal dari guru. Siswa cenderung pasif sehingga proses pembelajaran terasa kurang menyenangkan. Siswa hanya belajar jika diberi tugas atau latihan oleh guru, sehingga dapat disimpulkan bahwa siswa memiliki hasrat yang rendah melakukan kegiatan belajar.

Pembelajaran IPA cenderung bersifat abstrak. Oleh karena itu siswa menganggap IPA sebagai pelajaran yang membutuhkan banyak hafalan. Guru kurang merealisasikan konsepkonsep IPA kedalam sikap hidup dan perilaku yang nyata sehingga siswa hanya menerima pengetahuan yang bersifat teoritis saja. Siswa belum bisa secara mandiri belajar dan bekerja sama dalam memecahkan masalah yang dihadapi.

Dari permasalahan diatas dapat dikatakan bahwa motivasi siswa dalam pembelajaran IPA relatif rendah. Untuk menangani kondisi tersebut diperlukan penggunaan model pembelajaran yang bervariasi, bersifat menyenangkan dan sesuai dengan materi ajar yang diharapkan dapat menarik minat siswa dalam pembelajaran IPA. Salah satu model yang dapat memotivasi siswa untuk berperan aktif dalam pembelajaran adalah Word Square. Model pembelajaran Word Square adalah model pembelajaran yang berorientasi kepada keaktifan siswa dalam pembelajaran. Model ini memadukan kemampuan menjawab pertanyaan 
dengan kejelian dalam mencocokkan jawaban pada kotak jawaban. Model pembelajaran ini mampu sebagai pendorong dan penguat siswa terhadap materi yang disampaikan. Selain itu model ini juga mampu meningkatkan daya pikir siswa untuk mencocokkan jawaban pertanyaan yang dibutuhkan pada kotak-kotak jawaban yang tersedia.

Tujuan penelitian ini adalah Meningkatkan Motivasi Belajar Siswa dengan Menggunakan Model Pembelajaran Word Square pada Pelajaran IPA Materi Pengaruh Energi di Kelas IIIa SD Negeri 104204 Sambirejo Timur.

\section{METODE PENELITIAN}

Jenis penelitian ini adalah Penelitian Tindakan Kelas (PTK) dengan menggunakan model pembelajaran Word Square. Ciri khas PTK adalah adanya siklus-siklus yang merupakan suatu pemecahan menuju praktek pembelajaran yang baik. Penelitian ini bertujuan untuk meningkatkan motivasi siswa dalam pembelajaran IPA di kelas IIIa SD Negeri 104204 Sambirejo Timur T.A. 2017/2018. Sesuai dengan jenis penelitian ini, yaitu Penelitian Tindakan Kelas, maka penelitian ini memiliki beberapa tahap yang merupakan suatu siklus. Setiap siklus dilaksanakan sesuai dengan perubahan yang akan dicapai.

\section{HASIL DAN PEMBAHASAN}

Langkah pertama yang dilakukan oleh peneliti dilaksanakan pada hari Jumat 27 Januari 2017 yaitu memberikan surat izin pelaksanaan penelitian kepada kepala sekolah SD Negeri 104204 Sambirejo Timur dan menemui peneliti kelas $\mathrm{V}^{\mathrm{A}}$ untuk memberitahu dan meminta izin untuk melaksanakan penelitian di kelas tersebut kemudian mendiskusikan jadwal pelajaran IPA khususnya materi Pengaruh Energi. Pada akhirnya, setelah melakukan diskusi, peneliti menetapkan hari untuk penelitian yaitu hari Senin untuk membagikan angket pada kondisi awal , hari Selasa dan Jumat untuk melaksanakan siklus I dan II yang masing-masing 2 pertemuan.

Penelitian ini dilakukan di dalam kelas dengan menggunakan alat bantu berupa daftar checklist (observasi) dan angket. Daftar checklist (observasi) digunakan untuk melihat motivasi belajar siswa pada saat belajar di dalam kelas. Angket digunakan untuk mengetahui motivasi dan respon siswa pada saat sebelum dan sesudah pembelajaran.

mengetahui sejauh mana tingkat motivasi belajar siswa sebelum diterapkan model pembelajaran Word Square.

Dari keseluruhan siswa pada kondisi awal hasil angket dapat dilihat pada Gambar 1 berikut: 
Rouli Barimbing: Meningkatkan Motivasi Belajar ..

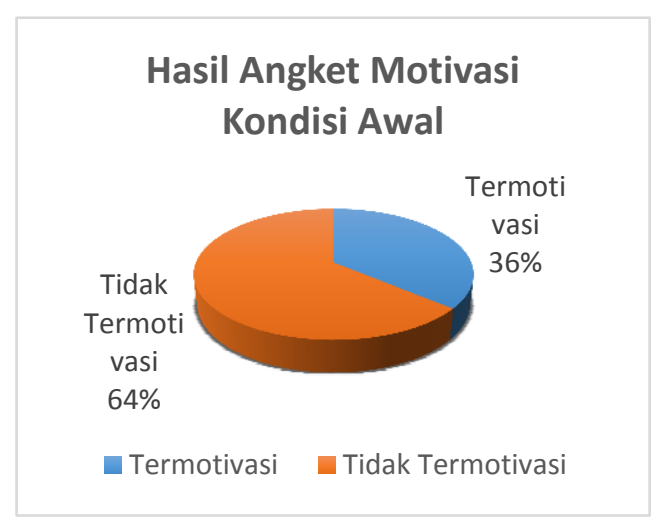

\section{Gambar 1. Hasil angket motivasi kondisi Awal}

Gambar 1. diatas terlihat bahwa motivasi belajar siswa terhadap pelajaran IPA masih sangat rendah. Dari 36 siswa, rata-rata motivasi belajar siswa yang diperoleh hanya sebesar 46,19\%. Kriteria motivasi belajar siswa dapat dikategorikan motivasi rendah, jumlah siswa yang termotivasi lebih sedikit dibandingkan dengan jumlah siswa yang tidak termotivasi. Jumlah siswa yang termotivasi 13 orang siswa (36\%) dan jumlah siswa yang tidak termotivasi 23 orang siswa $(64 \%)$.

Oleh karena itu, peneliti mengadakan perbaikan pengajaran dengan menggunakan penerapan model pembelajaran Word Square dalam meningkatkan motivasi belajar siswa pada pelajaran IPA materi Pengaruh Energi.

Kegiatan yang diamati dalam tahap ini bertujuan untuk mengetahui kesesuaian tindakan dengan rencana yang telah disusun dan guna mengetahui sejauh mana pelaksanaan tindakan dapat menghasilkan perubahan sesuai dengan apa yang dikehendaki. Peneliti, peneliti dan teman sejawat peneliti melakukan pengamatan dengan lembar observasi pada saat pembelajaran berlangsung, selain itu peneliti juga diobservasi oleh teman sejawat dalam proses pengajaran di dalam kelas dengan menggunakan model pembelajaran Word Square.

Adapun hasil observasi motivasi belajar siswa pada siklus I sebagai berikut:

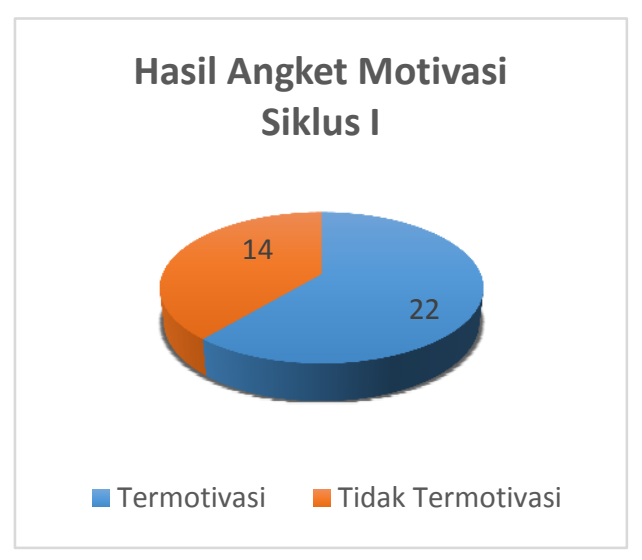

Gambar 2. Hasil Angket Motivasi

Gambar 2. diatas terlihat bahwa motivasi belajar siswa terhadap pelajaran IPA masih sangat rendah. Dari 36 siswa, rata-rata motivasi belajar siswa yang diperoleh hanya sebesar 22 Orang atau sekitar $61,1 \%$ termasuk kategori termotivasi sedangkan 14 orang atau sekitar $38,1 \%$. Peneliti melakukan refleksi 
terhadap seluruh kegiatan pada siklus I dengan hasil sebagai berikut. 1) Motivasi belajar siswa kelas III $^{\mathrm{A}}$ masih tergolong rendah. Hal ini dapat dilihat dari masih banyaknya siswa yang jenuh dalam belajar, kurang fokus belajar, tidak memperhatikan peneliti, tidak kreatif, tidak semangat mengerjakan tugas, tidak mempunyai motivasi berprestasi, cepat putus asa mengerjakan tugas, kurang percaya diri, tidak berani tampil di depan dan malu untuk mengemukakan pendapatnya. 2) Kurang optimalnya pembelajaran yang dilakukan peneliti saat belajar di kelas. Hal ini terlihat dari penjelasan materi yang dilakukan belum sistematis sehingga siswa merasa bingung, pengawasan kegiatan belajar yang dilakukan masih kurang, penertiban siswa masih kurang dan tidak ada memberikan tugas rumah.

Pelaksanaan pembelajaran pada siklus II dilaksanakan pada hari Jumat 17 Maret 2017. Pada siklus II ini peneliti melaksanakan kegiatan pembelajaran berdasarkan model pembelajaran Word Square. Pada pertemuan ini dilaksanakan diskusi kelompok. Sebelum memulai pelajaran peneliti membuka pelajaran seperti biasa yaitu mengucapkan salam, melakukan apersepsi yaitu dengan menanyakan materi yang telah dipelajari sebelumnya, menginformasikan tujuan pembelajaran yang akan dilakukan, kemudian memotivasi siswa agar semangat mengikuti proses pembelajaran di kelas.

\section{Hasil Angket Motivasi Siklus II}

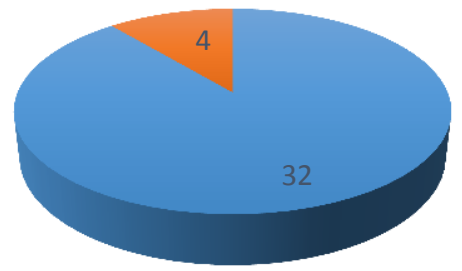

- Termotivasi $\quad$ Tidak termotivasi

\section{Gambar 3. Hasil Angkat Motivasi} Siklus II

Gambar. 3 diatas terlihat bahwa motivasi belajar siswa terhadap pelajaran IPA masih sangat rendah. Dari 36 siswa, rata-rata motivasi belajar siswa yang diperoleh hanya sebesar 32 Orang atau sekitar $88,8 \%$ termasuk kategori termotivasi sedangkan 4 orang atau sekitar $11,1 \%$.

Berdasarkan hasil observasi pada siklus II, maka peneliti melakukan refleksi terhadap seluruh kegiatan pada siklus II dengan hasil sebagai berikut: 1) Motivasi belajar siswa kelas $\mathrm{V}^{\mathrm{A}}$ telah mengalami peningkatan yang sangat pesat dan sudah mencapai harapan peneliti. Hal ini dapat dilihat dari hasil observasi motivasi belajar siswa yang menunjukkan seluruh siswa kelas III $^{\mathrm{A}}$ 
telah memiliki motivasi belajar.; 2) Siswa sudah memiliki sikap teliti, disiplin dan berfikir efektif. Siswa cukup aktif dan kreatif dalam belajar baik secara individu maupun berkelompok.

\section{Pembahasan}

Berdasarkan hasil penelitian yang telah dilakukan oleh peneliti dengan perolehan data yang diambil dari lembar observasi motivasi belajar siswa, angket, dan juga lembar observasi peneliti saat menerapkan model pembelajaran Word Square telah sesuai dengan harapan peneliti. Dengan hasil tersebut dapat disimpulkan bahwa dengan menerapkan model pembelajaran Word Square dapat meningkatkan motivasi belajar siswa khususnya pada pelajaran IPA materi Pengaruh Energi. Dengan demikian penelitian yang dilakukan dinyatakan Berhasil.

\section{SIMPULAN}

Berdasarkan hasil penelitian tindakan kelas yang dilakukan dengan menerapkan model pembelajaran Word Square pada materi Pengaruh Energi dapat disimpulkan sebagai berikut:

a. Penerapan model pembelajaran Word Square dapat meningkatkan motivasi belajar siswa karena dapat meningkatkan semangat siswa dalam mengerjakan soal yang berbentuk kotak-kotak seperti teka-teki silang, berusaha mengerjakan tugas-tugas dengan mendapatkan nilai maksimal, dapat membuat siswa teliti, disiplin dan aktif dalam pembelajaran.

b. Dengan menggunakan model pembelajaran Word Square dalam pelajaran IPA dapat meningkatkan motivasi belajar siswa..

c. Dari hasil observasi motivasi belajar siswa memperlihatkan bahwa terjadi peningkatan motivasi belajar siswa. Pada siklus I diperoleh data bahwa rata-rata persentase klasikal 55, $43 \%$ yang motivasi belajarnya tergolong sedang dan siklus II diperoleh data rata-rata persentase klasikal $88,31 \%$ yang motivasi belajarnya tergolong sangat baik

Pembelajaran dengan cara menerapkan model pembelajaran Word Square pada materi TokohTokoh Pergerakan Nasional dapat mengurangi kejenuhan dan kemalasan siswa dalam mengikuti pelajaran IPA dan dapat meningkatkan ketelitian dan kedisiplinan siswa.

\section{DAFTAR RUJUKAN}

Daryanto, dan Muljo Rahardjo. 2012. Model Pembelajaran Inovatif. Malang: Gava Media. 
Dewi,

$$
\text { Rosmala. }
$$

2010.

Profesionalisasi Guru Melalui PTK. Medan: Pasca Sarjana Unimed.

Dimyati, dan Mudjiono. 2009. Belajar dan Pembelajaran. Jakarta: Rineka Cipta.

Djaali, H. 2008. Psikologi Pendidikan. Jakarta: Bumi Aksara.

Djamarah, Syaiful Bahri. 2011. Psikologi Belajar. Jakarta: Rineka Cipta.

Faizi, Mastur. 2013. Ragam Metode Mengajarkan Eksakta pada Murid. Yogyakarta: Diva Press.

Huda, Miftahul. 2011. Cooperative Learning (Metode, Teknik, Struktur dan Model Terapan). Yogyakarta: Pusaka Pelajar.

Isjoni. 2009. Pembelajaran Kooperatif. Yogyakarta: Pustaka Belajar.

Istarani. 2010. Penelitian Tindakan Kelas (PTK). Medan: Iscom Medan.

Istarani. 2011. 58 Model pembelajaran Inovatif. Medan: Media Persada.

Purwanto, 2011. Evaluasi Hasil Belajar. Yogyakarta: Pustaka Belajar.

Rusman. 2012. Model-Model Pembelajaran mengembangkan
Profesionalime Guru. Jakarta: Rajawali Pers.

Sardiman. 2010. Interaksi dan Motivasi Belajar Mengajar. Jakarta: Rajawali Pers.

Uno, Hamzah B. 2011. Teori Motivasi dan Pengukurannya. Jakarta: Bumi Aksara.

Yamin, Martinis. 2011. Paradigma Baru Pembelajaran. Jakarta: Gaung Persada. 